\title{
Recent advances in the molecular biology of Leifsonia xyli subsp. xyli, causal organism of ratoon stunting disease
}

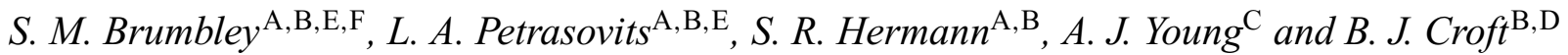 \\ ABSES Limited, 50 Meiers Road, Indooroopilly, Qld 4068, Australia. \\ ${ }^{B}$ Cooperative Research Centre for Tropical Plant Protection, John Hines Building, The University of Queensland, \\ Qld 4072, Australia. \\ ${ }^{\mathrm{C}}$ Department of Primary Industries and Fisheries, Mareeba, Qld 4880, Australia. \\ DBSES Limited, 90 Old Cove Road, Woodford, Qld 4514, Australia. \\ ${ }^{\mathrm{E}}$ Current address: Australian Institute for Bioengineering and Nanotechnology, The University of Queensland, \\ Qld 4072, Australia. \\ FCorresponding author. Email: s.brumbley1@uq.edu.au
}

\begin{abstract}
Twelve years ago our understanding of ratoon stunting disease (RSD) was confined almost exclusively to diagnosis of the disease and control via farm hygiene, with little understanding of the biology of the interaction between the causal agent (Leifsonia xyli subsp. xyli) and the host plant sugarcane (Saccharum spp. hybrids). Since then, research has focused on developing the molecular tools to dissect $L$. xyli subsp. xyli, so that better control strategies can be developed to prevent losses from RSD. Within this review, we give a brief overview of the progression in research on $L . x y l i$ subsp. xyli and highlight future challenges. After a brief historical background on RSD, we discuss the development of molecular tools such as transformation and transposon mutagenesis and discuss the apparent lack of genetic diversity within the $L$. xyli subsp. xyli world population. We go on to discuss the sequencing of the genome of $L . x y l i$ subsp. $x y l i$, describe the key findings and suggest some future research based on known deficiencies that will capitalise on this tremendous knowledge base to which we now have access.
\end{abstract}

Additional keywords: genome decay, genome uniformity, lateral gene transfer, pathogenicity, virulence.

\section{Introduction}

Ratoon stunting disease (RSD) of sugarcane (Fig. 1), first discovered in 1944 (McDougall et al. 1948), is caused by Leifsonia xyli subsp. xyli (Davis et al. 1980), a Gram positive, coryneform, xylem-limited phytopathogen (Fig. 2) (Kao and Damann 1980). Leifsonia xyli subsp. xyli is the most economically important pathogen of sugarcane worldwide, with losses in infected plants ranging from less than 5\% to more than 30\% (Steib and Chilton 1968; Koike et al. 1982; Bailey and Bechet 1997). Generally, the symptoms of stunting (Fig. 1) and poor ratooning ability are believed to be the result of vascular plugging (Kao and Damann 1980). However, L. xyli subsp. xyli produces no other reliable external or internal symptoms (Gillaspie and Teakle 1989) and it is currently unknown whether this plugging is caused by something produced by the bacterium, is a plant defence response, or a combination of both.
Initially it was thought that RSD was caused by a virus because axenic culture of the bacterium was unsuccessful (Steindl 1957). It was not until the 1970s that a bacterium was found to be associated with infected plants (Gillaspie et al. 1973; Kao and Damann 1978) and not until the 1980s that it was successfully grown in pure culture and Koch's postulate confirmed it to be the causal agent of RSD (Davis et al. 1980, 1984) (Fig. 2). Leifsonia xyli subsp. xyli was originally described in the genus Clavibacter (Davis et al. 1984), based on phenotypic characteristics (Fig. 3), but recently was reviewed and placed in the genus Leifsonia (Evtushenko et al. 2000) based on rRNA gene analysis. This classification was recently confirmed by Young et al. (2006).

Little is known of the origin and early disseminations of RSD. It is unlikely that $L$. xyli subsp. xyli is naturally associated with the main progenitor of modern commercial sugarcane varieties, Saccharum officinarum, because the bacterium has previously never been found in populations of 


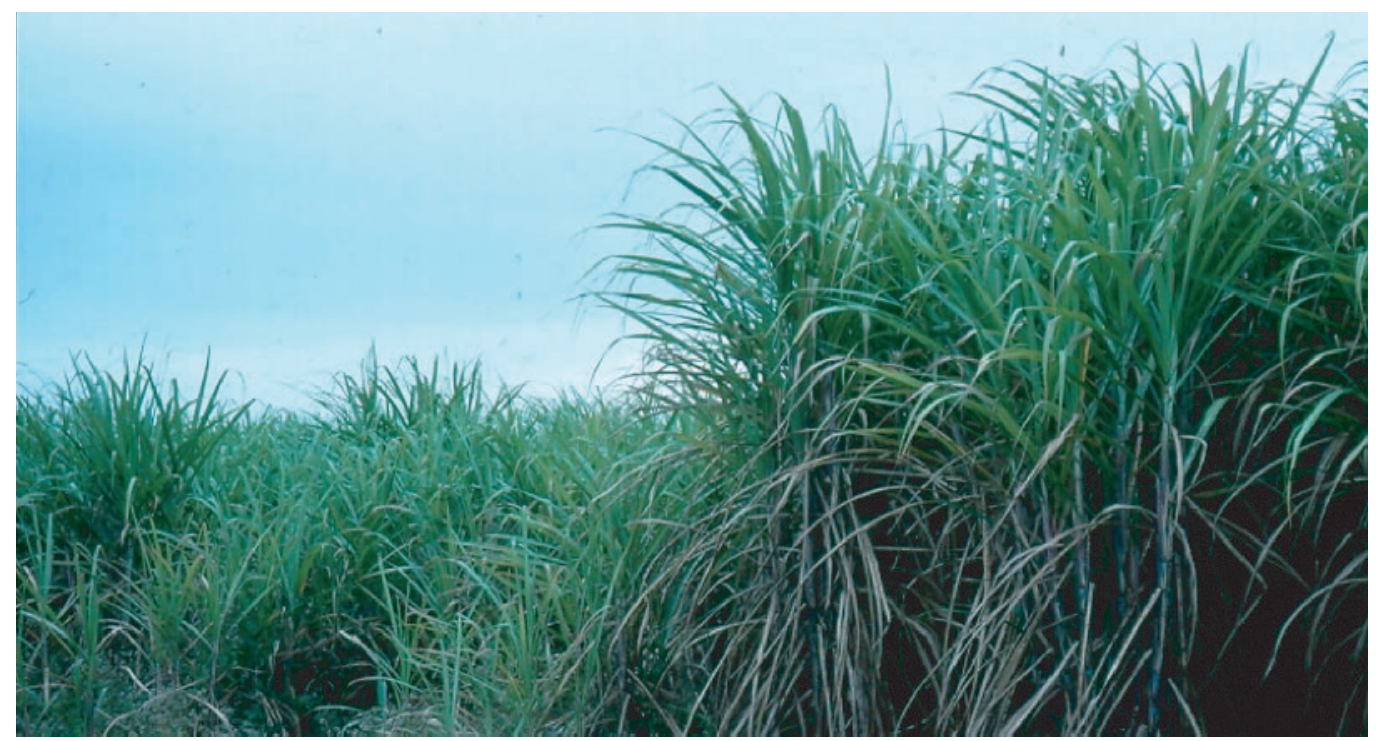

Fig. 1. Sugarcane variety Q124 infected with Leifsonia xyli subsp. xyli (left) growing side-by-side with healthy Q124 (right). Ratoon stunting disease losses can be severe when plants infected with Leifsonia xyli subsp. xyli are used as the plant cane and the cane experiences water stress. The image shows the first ratoon crop; the plant crop was harvested and this is the crop that grows back after the first harvest (ratoon) from the stool left in the ground. In Queensland, the sugarcane crop is normally harvested 4 or 5 times before a plough out and replant is required. However, with losses such as these, the crop may have to be ploughed out and replanted sooner. Photograph taken in Mackay, Queensland and is from the BSES Limited photo archives.

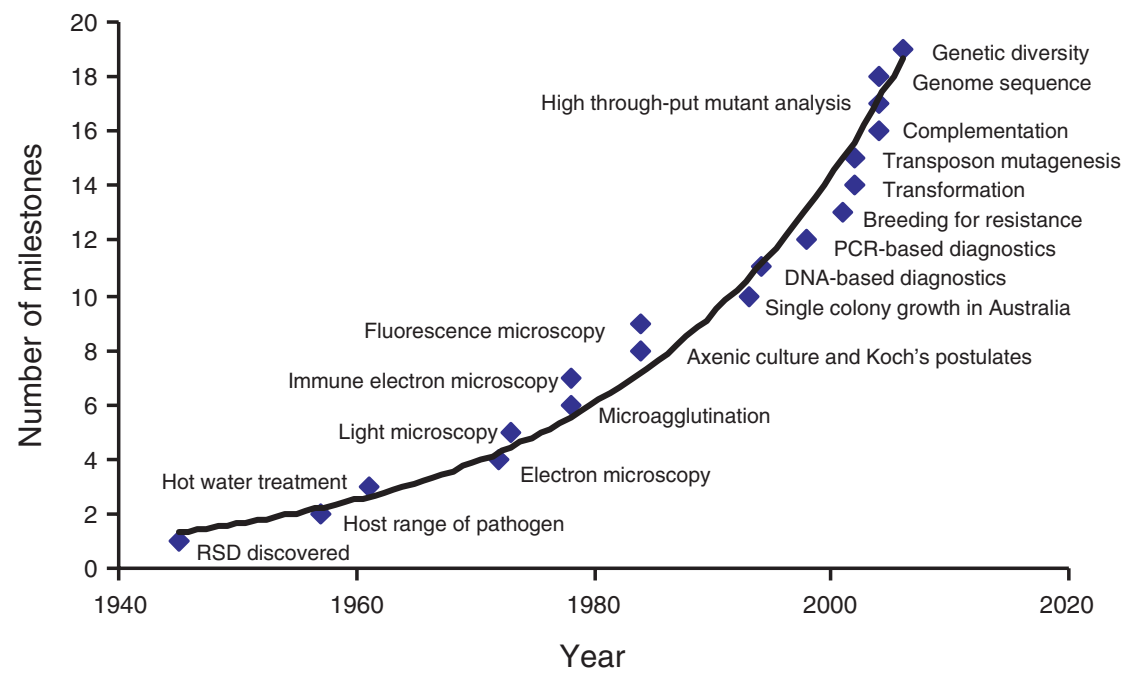

Fig. 2. Significant break-throughs in ratoon stunting disease research since the discovery of the disease in $1944-45$.

this grass species throughout its centre of origin, Papua New Guinea (see King 1953; Hughes 1955), and only recently has become established in commercial plantation on the Ramu estate in this country (Magarey et al. 2002). Based on its xylem habitat, restricted host range (Rao et al. 1990), close relationship with another grass endophyte (Leifsonia xyli subsp. cynodontis) and certain genomic features (Monteiro-Vitorello et al. 2004), the bacterium appears to have had a long association with grasses. Interestingly, clones of the wild cane, Saccharum spontaneum, support $>10$ times the bacterial titres of $L$. xyli subsp. xyli than infected S. officinarum (Roach 1988, 1990; Roach and Jackson 1992), suggesting that the bacteria are better adapted to the former plant, and may share a longer history of interaction. Saccharum spontaneum was hybridised with $S$. officinarum in the 1920 s to produce the first of the modern hybrid cultivars, which coincides with the first reports of ratooning problems and varietal yield decline 


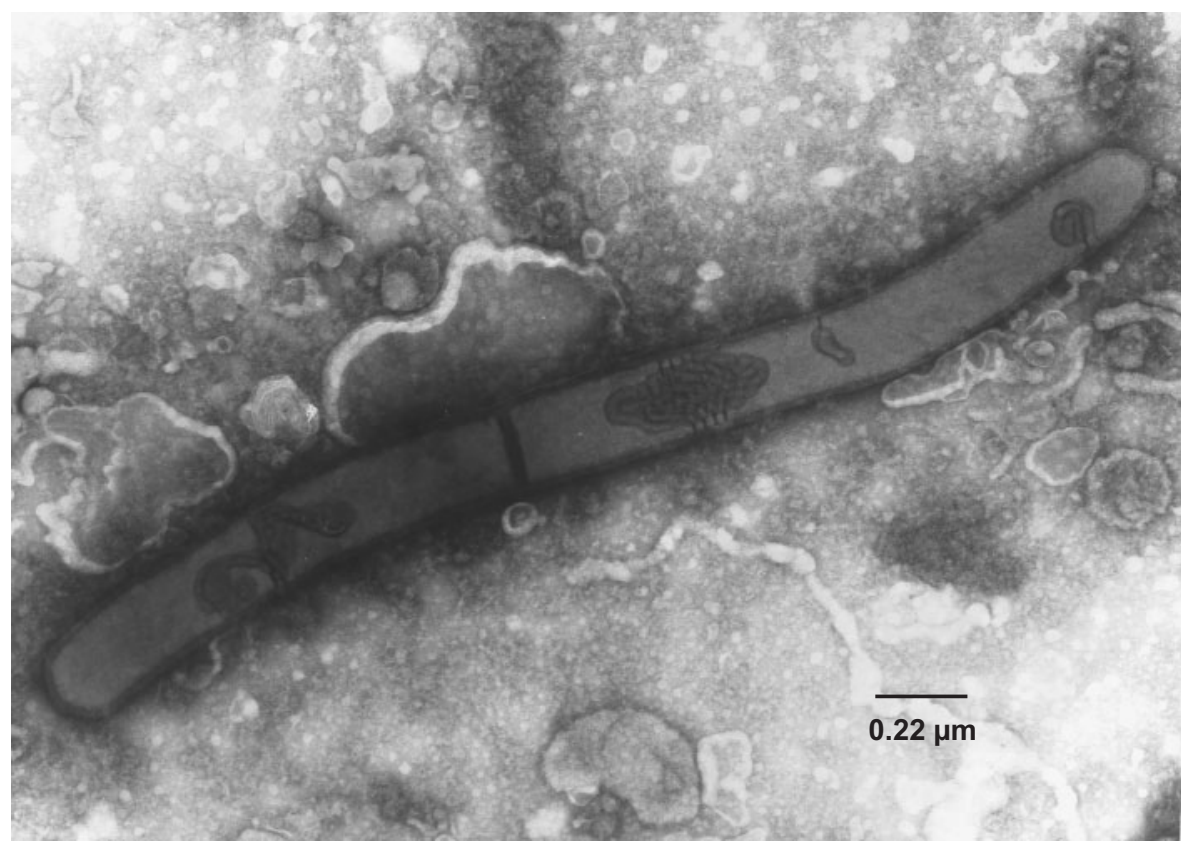

Fig. 3. Electron micrograph of dividing L. xyli subsp. xyli cells originally isolated from nodal exudate from sugarcane variety Q77 on 22 June 1973. Note the 4 distinct mesosomes, 3 in the longer cell and 1 in the other. L. xyli subsp. xyli cells measure $195-220 \mathrm{~nm}$ in diameter. Length of the two cells together is $2610 \mathrm{~nm}$. Because this sample was dried as part of the fixation process these sizes are most likely smaller than a living bacterium. $L$. xyli subsp. xyli cells will not fit through a $0.22-\mu \mathrm{m}$ filter but will fit through a $0.40-\mu \mathrm{m}$ filter. These rods can have swelling on one end giving them the appearance of a club-shaped rod, hence the original name, Clavibacter. Photograph courtesy of Prof. David Teakle.

(Anon. 1934; King and Steindl 1953). While speculative, the emergence of RSD from $S$. spontaneum endophytes at the dawn of the modern sugar industry would facilitate the world-wide distribution of a single strain of $L$. xyli subsp. xyli. Support for this hypothesis has been provided by the genetic diversity studies of Young et al. (2006).

An effective control strategy for RSD had been developed even before the causal agent was identified. This involved provision of disease-free planting material and disinfection of cutting implements that could spread the disease (Taylor et al. 1988) (Fig. 2). Currently in Australia, disease-free planting material is provided by local productivity services who have established disease-free plots of cane by routine hot-water treatment (for review, see Steindl 1961). This material is sold to growers, who plant the cane into an on-farm nursery from which they plant their commercial fields. Using this system, Australia, which has one of the world's best records at controlling the disease (Bailey and Bechet 1997; Croft et al. 2004) has been able to contain the overall incidence of RSD to less than $5 \%$ with some districts below $1 \%$. However, a few districts have a $20 \%$ incidence of RSD (Croft et al. 2004).

\section{Diagnostic methods}

There are no reliable internal or external symptoms of RSD. It is readily spread both within a field and between fields and farms on infected planting and harvesting machinery (Taylor et al. 1988). In many countries, clean-seed schemes and heat treatment of planting material are important factors in the management of RSD. However, these methods are expensive and labour-intensive and may not always eradicate the causal agent, L. xyli subsp. xyli (Damann and Benda 1983; Roach 1987). Efficient diagnostic tests are, therefore, crucial to the management of the disease (Gillaspie and Teakle 1989).

Initially, diagnosis of the disease was performed by inoculation of susceptible sugarcane cultivars and/or other grass species with test-plant juice (Steindl 1957; Matsuoka 1971; Mills et al. 2001), by electron microscopy (Plavsic-Banjac and Maramorosch 1972) (Fig. 2) and other microscopic techniques (Gillaspie et al. 1973) (Fig. 3). Major disadvantages of these techniques include slowness, lack of sensitivity and the requirement for highly trained operators and/or expensive equipment. The identification of L. xyli subsp. xyli as the causal agent of RSD (Davis et al. 1980) greatly facilitated the development of serological (Davis and Dean 1984; Croft et al. 1994) and DNA-based diagnostic tests (Chung et al. 1994; Pan et al. 1998; Fegan et al. 1998; Taylor et al. 2003) (Fig. 2). Chung et al. (1994) used cloned DNA from $L$. xyli subsp. xyli as probes in Southern and dot blot hybridisations while Pan et al. (1998) and Fegan et al. (1998) both used the intergenic 
transcribed spacer regions of the 16S-23S rRNA genes to develop diagnostic primers for polymerase chain reaction (PCR)-based assays. Taylor et al. (2003) also used a PCR technique but developed $L$. xyli subsp. xyli specific diagnostic primers derived from PCR products amplified using random amplified polymorphic DNA primers (OPC2 and OPC11; Operon Technologies, USA). Although these techniques are recognised as being sufficiently sensitive, relatively inexpensive and efficient, due care must be exercised, especially when interpreting negative test results, as current sampling strategies only encompass as little as $0.2 \%$ of a given field population (Young and Brumbley 2004). Additionally, all serological techniques for the detection of this bacterium rely on polyclonal antisera raised against whole bacteria. The detection limit is $\sim 10^{4}$ cells $/ \mathrm{mL}$ xylem fluid (Davis and Dean 1984), which might be improved by the use of a monoclonal antibody.

\section{Improved culture conditions for axenic growth}

In 1993, L. xyli subsp. xyli was grown in Australia by placing a drop of xylem extract from an infected sugarcane plant on the surface of a MSC-agar plate and incubating at $28^{\circ} \mathrm{C}$ until the spot was a confluent growth of $L$. xyli subsp. xyli cells (B. J. Croft, unpublished data). Cells were propagated by carefully harvesting bacteria from plates, resuspension in sterile water and subsequent spotting of droplets onto fresh MSC-agar plates. For molecular biological investigation of pathogenicity, it was necessary to establish a method for single-colony growth. This was accomplished by growing bacterial cultures on MSC medium (Teakle and Ryan 1992), modified to have increased agar levels so the media was firm enough to spread-plate or streak onto (Brumbley et al. 2002) (Fig. 2). Since L. xyli subsp. xyli is so slow-growing (at $28^{\circ} \mathrm{C}$ it takes 4 weeks to see visible single colonies after streaking or spread-plating) antibiotic selection pressure was improved by growing cultures on nitrocellulose filters $(0.2 \mu \mathrm{m}$ pore size; L. xyli subsp. xyli can fit through a $0.45 \mu \mathrm{m}$ pore) with weekly transfers to fresh medium (twice a week for ampicillin) (Brumbley et al. 2002). Although L. $x y l i$ subsp. $x y l i$ was resistant to nalidixic acid, it was highly susceptible to ampicillin $(100 \mu \mathrm{g} / \mathrm{mL})$, tetracycline $(2 \mu \mathrm{g} / \mathrm{mL}$, S. M. Brumbley et al., unpublished data) and kanamycin $(50 \mu \mathrm{g} / \mathrm{mL})$.

To generate electroporation competent cells and to grow cells for DNA isolation and for inoculation studies, it was necessary to grow $L$. xyli subsp. xyli in liquid media. Brumbley et al. (2002) demonstrated that for the bacterium to grow efficiently in broth culture it was necessary to increase the concentrations of $\mathrm{KH}_{2} \mathrm{PO}_{4}$ and sucrose and decrease the concentrations of $\mathrm{K}_{2} \mathrm{HPO}_{4}$ and cysteine in the $\mathrm{S} 8$ medium described in Davis et al. (1980). In addition, it was shown that the addition of glycine improved the ability to make electroporation competent cells and to extract high quality genomic DNA from L. xyli subsp.xyli (Brumbley et al.2002).

\section{Transformation and transposon mutagenesis of L. $x y l i$ subsp. $x y l i$}

Brumbley et al. (2002) described the transformation of L. xyli subsp. xyli with the Clavibacter/E. coli shuttle vectors pDM302 and pDM306 (Meletzus et al. 1993) and pLUX19 (Mudge et al. 1996) (Fig. 2). These constructs were highly unstable in this bacterium (Brumbley et al. 2002). By contrast, cosmid vectors harbouring the RP4 broad host range origin of replication, derived from pLAFR3 (Staskawicz et al. 1987) and pLAFR5 (Keen et al. 1988), proved to be highly stable. A pLAFR5 derivative harbouring a kanamycin resistance marker (pLAFR5-km: Brumbley et al. 2002) was used for the construction of a genomic library of 1920 clones giving an estimated 15-X coverage of the L. xyli subsp. xyli genome (Brumbley et al. 2002).

Transposon mutagenesis is used to generate knockout mutants. Transposons are introduced into bacteria on a suicide vector incapable of replicating in the host and when they translocate from the vector into the host genome and insert into a gene, its functionality is usually abolished. Brumbley et al. (2002) used the suicide vector pUCD623 (Shaw et al. 1988) to generate over 700 transposon mutants of $L$. xyli subsp. xyli. This vector harbours the transposable element $\mathrm{Tn} 4431$ containing a tetracycline resistance marker gene and the promoterless lux-operon from Vibrio fischeri.

Since $L$. xyli subsp. xyli does not produce reliable external symptoms in sugarcane, a robust colonisation assay was developed (Brumbley et al. 2004). A range of inoculation techniques was trialled (Young and Brumbley 2004). Inoculation of 6- to 8-week-old sugarcane plants with $L$. xyli subsp. xyli wild-type or mutant cells by decapitation above the apical meristem and transfer of a $100 \mu \mathrm{L}$ aliquot of bacterial culture to the freshly cut surface worked best. It was also demonstrated that addition of filtersterilised xylem extract from L. xyli subsp. xyli-infected sugarcane enhanced colonisation of sugarcane (Young and Brumbley 2004). Xylem fluid was collected 3 months after inoculation and analysed by evaporative-binding enzymelinked immunoassay (Croft et al. 1994; Brumbley et al. 2004). Using this technique, three mutants that had lost the ability to colonise sugarcane were identified, one of which was selected for further analysis. Flanking DNA from the transposon insertion in this mutant was cloned, sequenced and used as a probe to isolate two overlapping cosmid clones, pLB1C2 and pLB1D6, from the $L$. $x y l i$ subsp. $x y l i$ cosmid library (Brumbley et al. 2004). The insertion of the transposon was in an open reading frame with weak homology to a hypothetical integral membrane protein from Mycobacterium tuberculosum. Two putative operons were identified in the immediate vicinity of the insertion site, both of which encode genes implicated in pathogenesis (Brumbley et al.2004). To complement the mutation, we transformed the mutant with the cosmid pLB1C2, which restored the ability of this mutant to colonise sugarcane. However, because a 
cosmid clone harbouring multiple genes was used in the complementation studies, it was not possible to determine whether the mutant's inability to colonise sugarcane was the result of transposon insertion or the result of a spontaneous mutation in one of the other genes encoded on the cosmids (Brumbley et al. 2004). Further work, such as markerexchange studies, is required to confirm this.

\section{Genetic uniformity of $L$. $x y l i$ subsp. xyli}

Young et al. (2006) have provided a comprehensive study of the genetic variability within $L$. xyli subsp. xyli. Using a variety of techniques, no variation was detected among 105 different isolates of the L. xyli subsp. xyli from nine countries. Furthermore, no diversity was found when the DNA flanking 461 different transposon mutants, all generated in Australian isolates of $L$. xyli subsp. $x y l i$, was sequenced. When these were compared to equivalent sequences in the genome of Brazilian isolates (Monteiro-Vitorello et al. 2004), they were shown to have $100 \%$ homology.

\section{L. $x y l i$ subsp. $x y l i$ genome sequencing project}

The genome of a Brazilian L. xyli subsp. xyli isolate (CTCB07) was sequenced fully by the Agronomic and Environmental Genomics Group (AEG) in Brazil (MonteiroVitorello et al. 2004). The genome is $2.6 \mathrm{Mb}$ in size, contains $\sim 2022$ open reading frames and has a GC content of $68 \%$, (Monteiro-Vitorello et al. 2004).

Several interesting characteristics were discovered within the $L$. xyli subsp. xyli genome. There is evidence that at one time $L$. $x y l i$ subsp. $x y l i$ could function as a free-living organism, it has a surprisingly large number of pseudogenes and there is evidence that it imported some genes required for its survival in sugarcane from other organisms. In addition, L. $x y l i$ subsp. $x y l i$ has genes that help it adapt and survive in its host plant, sugarcane.

\section{Free-living state}

The life cycle of $L$. xyli subsp. xyli appears to be limited to the xylem vessels of sugarcane plants. As discussed above, the bacterium can colonise other grass species in experimental systems, but it has never been found to naturally colonise any other grass or been found living free in the environment (Gillaspie and Teakle 1989).

Evidence that $L$. $x y l i$ subsp. $x y l i$ is, or used to be, able to survive outside of sugarcane xylem vessels, free-living in the environment, is shown by the fact that there are a large number $(n=30)$ of $\mathrm{ABC}$ transporter homologues, indicating it can utilise a large range of carbohydrates (Monteiro-Vitorello et al. 2004). In addition, this bacterium harbours homologues of photolyase and flagellar operons, two $\mathrm{ABC}$ glycine and betaine transporters, genes that protect against changes in the osmotic condition and genes for carotenoid biosynthesis. These all suggest that at one time it had a free-living life form (Monteiro-Vitorello et al. 2004).

\section{Genome decay and pseudogenes}

There is evidence that $L$. xyli subsp. $x y l i$ is undergoing genome decay, based on what appear to be 310 pseudogenes (i.e. gene fragments arising from frameshifts or deletions or caused by point mutations that introduce or remove stop codons, or incomplete genes), comprising $13 \%$ of the total number of predicted genes in this organism's genome (Monteiro-Vitorello et al. 2004) (Table 1). Other actinomycetes also undergoing genome decay, such as Mycobacterium leprae, causal organism of leprosy, have more pseudogenes (905, or $34.1 \%$ of its genes) (Cole et al. 2001), but $L$. xyli subsp. xyli has the highest level seen in any of the plant-associated bacteria whose genomes have been sequenced. Monteiro-Vitorello et al. (2004) believe this decay is brought about by the process of host adaptation and narrow host range (Table 1). This large number of

Table 1. Number of pathogenicity genes and pseudogenes in six species of bacterial phytopathogens All data compiled from Monteiro-Vitorello et al. (2004). Rs, Ralstonia solanacearum; Xf, Xylella fastidiosa 9a5C; Xcc, Xanthomonas campestris pv. campestris; Xac, Xanthomonas axonopodis pv. citri; Atu, Agrobacterium tumefaciens C58; Lxx, Leifsonia xyli subsp. xyli CTC B07

\begin{tabular}{|c|c|c|c|c|c|c|}
\hline \multirow[t]{2}{*}{ Category } & \multicolumn{6}{|c|}{ Species } \\
\hline & Rs & $\mathrm{Xf}$ & $\mathrm{Xcc}$ & $\mathrm{Xac}$ & Atu & Lxx \\
\hline Type III secretion system related function & 34 & 0 & 35 & 35 & 0 & 0 \\
\hline Toxin production and detoxification & 133 & 69 & 111 & 134 & 93 & 27 \\
\hline Host cell wall degradation & 13 & 6 & 24 & 20 & 4 & 6 \\
\hline Exopolysaccharides & 0 & 9 & 14 & 15 & 3 & 3 \\
\hline Surface proteins & 35 & 6 & 11 & 14 & 28 & 31 \\
\hline Adaptation to atypical conditions & 22 & 16 & 26 & 25 & 21 & 36 \\
\hline Other relevant genes ${ }^{\mathrm{A}}$ & 33 & 28 & 66 & 59 & 57 & 2 \\
\hline Total pathogenicity and virulence & 270 & 134 & 287 & 302 & 206 & 105 \\
\hline Pseudogenes & 38 & 66 & 73 & 85 & 13 & 307 \\
\hline Protein-coding genes & 5036 & 2249 & 4181 & 4427 & 5415 & 2326 \\
\hline
\end{tabular}

${ }^{\mathrm{A}}$ Genes involved in pathogenicity or virulence not listed in the above categories. 
pseudogenes is an indicator of $L$. xyli subsp. xyli adapting to living exclusively in the xylem vessels of sugarcane. Examples of $L$. xyli subsp. xyli pseudogenes include 51 transposase-encoding genes, 4 of 28 flagellar operon genes, 14 of $30 \mathrm{ABC}$ transporters, genes for metabolism of galactose and glutarate and for the synthesis of cysteine and methionine, and, most importantly, 20 of 105 putative virulence and pathogenicity genes (Monteiro-Vitorello et al. 2004). These 105 genes for virulence and pathogenicity found in L. xyli subsp. xyli present by far the smallest number found in any of the phytopathogenic bacteria sequenced: $20 \%$ smaller than Xylella fastidiosa, which colonises the xylem of citrus, and $60 \%$ smaller than two Xanthomonas species (Monteiro-Vitorello et al. 2004) (Table 1).

The large number of dysfunctional genes explains the nutritional fastidiousness of $L . x y l i$ subsp. xyli and indicates why it has only been found living in the xylem of sugarcane. Monteiro-Vitorello et al. (2004) suggest that if these pseudogenes were intact, $L$. xyli subsp. xyli would be able to live on plant debris and the flagella would allow it to move about more freely.

\section{Lateral gene transfer and genomic islands}

Within the genome of $L . x y l i$ subsp. xyli, there are several regions with altered GC content, and in some of these regions there are also altered codon bias and dinucleotide signatures, suggesting that these regions (genomic islands) may have been acquired from other organisms (MonteiroVitorello et al. 2004). Three of these islands contain possible pathogenicity genes, including pectinase and cellulase homologues, both of which would be involved in cell wall degradation. This may be one way that $L$. xyli subsp. xyli extracts some of its nutrients from sugarcane, although there is no evidence of this in any of the electron micrographs shown in the literature (Kao and Damann 1978, 1980).

In addition to these cell wall-degrading enzymes, one of the genomic islands also has a gene similar to Pat-1 (Monteiro-Vitorello et al. 2004) of Clavibacter michiganensis subsp. michiganensis, which probably plays a significant role in plant wilting (Dreier et al. 1997).

The other potential pathogenicity genes residing in these genomic islands may be involved in the production of abscisic acid, a plant growth inhibitor which may play a role in the stunting from which the disease derives its name (MonteiroVitorello et al. 2004).

\section{Host adaptation}

There is another sugarcane pathogen, Xanthomonas albilineans, which also colonises the vascular system of sugarcane and produces a toxin responsible for the primary symptom, leaf scald (Rott et al. 1994). The L. xyli subsp. xyli genome encodes a multi-drug efflux pump similar to that found in $X$. albilineans, which would allow $L$. xyli subsp. $x y l i$ to survive in sugarcane plants also infected with the leaf scald pathogen (Monteiro-Vitorello et al. 2004). The genome of $L$. xyli subsp. xyli, similar to those of other plant pathogens, encodes several gene products to allow it to survive host defence mechanisms such as reactive oxygen species. (Monteiro-Vitorello et al. 2004) (Table 1).

\section{Discussion}

Leifsonia xyli subsp. xyli is an extremely difficult bacterium to study. Not only does it not produce reliable external symptoms on or in its host plant sugarcane, but under irrigation or adequate rainfall, the stunting symptom can be reduced to the point where it is imperceptible. When this is compounded with the difficulties of growing this bacterium in axenic culture, it is not surprising that so little work was done previously to understand how this insidious pathogen interacts and causes disease on sugarcane. Biotechnology has allowed us to dramatically reverse this situation, to the point now where we can start to design key experiments to understand how this bacterium causes disease on sugarcane and to start devising strategies to control and even eradicate this costly pathogen from sugarcane growing regions around the world.

Our ability to transform and generate mutants of L. xyli subsp. $x y l i$ were critical first steps to understanding the functions of key genes and with the full genome sequenced we now have a good idea of what some of those key genes are. However, we still lack at least one critical tool to help us advance this work. It is possible to do random mutagenesis on L. xyli subsp. xyli, but site-directed mutagenesis techniques, such as marker exchange (He and Collmer 1990) have not been successful. Random mutagenesis is too slow; it took over a year to generate the 700 random mutants with Tn4431 (Brumbley et al. 2002), whereas marker exchange should allow the knock out of specific genes selected from the genome database almost on a monthly basis: the time it takes to grow L. xyli subsp. xyli in axenic culture on solid media. To help select genes for knockout mutagenesis studies, oligonucleotide microarrays could be generated, which would include targets for either every putative gene in the $L$. xyli subsp. xyli genome or selected subsets of genes (Okinaka et al. 2002; Hinton et al. 2004; Lu et al. 2005). To generate the probes for these microarrays, mRNA would be isolated from $L$. xyli subsp. xyli grown under various conditions. For instance, S8 broth cultures of L. xyli subsp. xyli could be spiked with filter-sterilised xylem extract from healthy and $L$. xyli subsp. xyli infected sugarcane plants and these arrays compared to ones probed with nonspiked cultures and with L. xyli subsp. xyli isolated from xylem of infected sugarcane plants (Okinaka et al. 2002). In addition to microarrays, analysis of $L$. xyli subsp. xyli wild-type and various knock out mutants could include any of the powerful 'omics' tools, and in particular proteomics tools. To date, most proteomics used in plant-microbe interaction studies have focused on the host plant; however, 
these technologies have excellent potential in pathogen identification (Padliya and Cooper 2006). Comparison of total cell proteins from $L$. xyli subsp. xyli cultures by twodimensional gel electrophoresis could help identify key proteins that are differentially produced during the interaction between $L$. xyli subsp. xyli and sugarcane.

Proteomics could be used to study the impact of individual mutants on overall protein production, especially in relation to the regulatory networks that help trigger host plant recognition and colonisation. Again, pure cultures of L. $x y l i$ subsp. $x y l i$, spiked with xylem extracts collected from healthy and infected sugarcane, could be compared to nonspiked cultures and with $L$. xyli subsp. xyli total proteins from cells isolated from infected sugarcane xylem vessels. Controls would include protein extracted from a similar volume of the culture media and of xylem extract from healthy sugarcane plants.

Comparative genomics is another tool that is already being used to help us understand pathogenicity, host range and virulence (Toth et al. 2006). The power of this, combined with functional genomics, will only be enhanced as more genomes are added to the databases. Several genes have already been identified in the L. xyli subsp. xyli genome data that would be worth further study. The xylem vessels of sugarcane do not contain high levels of nutrients. A study of the composition of xylem fluid in healthy sugarcane compared to that of xylem fluid from plants infected with $L$. xyli subsp. xyli should give us clues as to which of the functional $\mathrm{ABC}$ transporters would be critical for the survival $L$. xyli subsp. xyli in this environment. Leifsonia xyli subsp. xyli has only 105 genes categorised as pathogenicity related and 20 of these are predicted to be pseudogenes (Monteiro-Vitorello et al. 2004). A careful analysis of these genes should reveal candidates for knock out mutagenesis studies. There is also evidence of quorum sensing capabilities within the genome (von Bodman et al.2003). Transgenic plants expressing enzymes that break down the quorum-sensing signal have shown significant resistance to infection by bacterial pathogens (Dong et al. 2000, 2001; Zhang 2003). If genes encoding these enzymes were under the control of a wound-inducible promoter that switched on when the crop is harvested, this could prevent one of the main forms of transmission. Something similar could be done with a $L$. $x y l i$ subsp. $x y l i$-specific antibody such as the ones already used in our ELISA screening or one made specifically for one of the putative cell surface proteins identified in the genome database (Monteiro-Vitorello et al. 2004). This antibody could also be used as an improved diagnostic tool.

There are several virulence factors identified in the $L$. $x y l i$ subsp. $x y l i$ genome database that are also worth closer scrutiny. Two are cell wall-degrading enzymes, a pectinase and a cellulase (Monteiro-Vitorello et al. 2004), which may be involved in nutrient extraction from the xylem vessels and also may trigger the host defence, the production of the gelatinous material found to plug xylem vessels of sugarcane plants infected with $L$. xyli subsp. xyli (Kao and Damann 1978). The third, and one that Monteiro-Vitorello et al. (2004) state deserves special attention, may be involved in the synthesis of the plant hormone abscisic acid, which has been reported to be a plant growth inhibitor. This gene could be involved in the stunting and reduced tillers seen in sugarcane infected with $L$. xyli subsp. xyli.

\section{Conclusions}

The tools have now been assembled to rapidly advance our understanding of how $L$. xyli subsp. xyli can recognise sugarcane as a host, colonise its xylem vessels and cause $\mathrm{RSD}$, and there are new tools on the horizon. Unlike most plant pathogens, the L. xyli subsp. xyli genome has been sequenced and is in the public domain. Establishment of the L. xyli subsp. xyli transcriptome and proteome databases will be major milestones for this pathogen and will be valuable tools for researchers, with practical uses for the sugarcane industry. At the gene expression level, genome and transcriptome tools can be used to study how $L$. xyli subsp. xyli responds to first contact with sugarcane as it moves from cutting and planting machinery to the cut surface of a sugarcane stalk. The proteome, will allow studies of how L. $x y l i$ subsp. $x y l i$ responds at the protein level and can be used to develop highly sensitive diagnostic tools. Because L. xyli subsp. xyli does not appear to colonise other plant species and it does not appear to be able to survive in the soil, it may be possible to devise a strategy to eradicate this disease from our sugarcane industries. This is a worthwhile goal, because RSD is still considered to be one of the most economically important diseases of sugarcane worldwide.

\section{Acknowledgements}

We extend our sincere gratitude to the Sugar Research and Development Corporation and the Cooperative Research Centre (CRC) for Tropical Plant Pathology and the CRC for Tropical Plant Protection for their generous funding over the years. We give special thanks to Drs Peter Allsopp, and John Manners for their critical review of this manuscript.

\section{References}

Anon. (1934) '34th Annual report. 1934.' (Bureau of Sugar Experiment Stations: Brisbane)

Bailey RA, Bechet GR (1997) Further evidence of the effects of ratoon stunting disease on production under irrigated and rainfed conditions. Proceedings of the South African Sugar Technology Association 71, 97-101.

von Bodman SB, Bauer WD, Coplin DL (2003) Quorum sensing in plant-pathogenic bacteria. Annual Review of Phytopathology 41, 455-482. doi: 10.1146/annurev.phyto.41.052002.095652

Brumbley SM, Petrasovits LA, Birch RG, Taylor PWJ (2002) Transformation and transposon mutagenesis of Leifsonia xyli subsp. $x y l i$, causal organism of ratoon stunting disease of sugarcane. Molecular Plant-Microbe Interactions 15, 262-268. 
Brumbley SM, Petrasovits LA, Murphy RM, Nagel RJ, Candy JM, Hermann SR (2004) Establishment of a functional genomics platform for Leifsonia xyli subsp. xyli. Molecular Plant-Microbe Interactions 17, 175-183.

Chung CH, Lin CP, Chen CT (1994) Development and application of cloned DNA probes for Clavibacter xyli subsp. xyli, the causal agent of sugarcane ratoon stunting. Journal of Phytopathology 141, 293-301.

Cole ST, Eiglmeier K, Parkhill J, James KD, Thomson NR et al. (2001) Massive gene decay in the leprosy bacillus. Nature 409, 1007-1011. doi: 10.1038/35059006

Croft BJ, Greet AD, Lehmann TM, Teakle DS (1994) RSD diagnosis and varietal resistance screening in sugarcane using the EB-EIA technique. Proceedings of the Australian Society of Sugar Cane Technologists 16, 143-151.

Croft BJ, Green J, Parsons D, Royal A (2004) BSES RSD laboratories 10 years of service. Proceedings of the Australian Society of Sugar Cane Technologists 26, 24.

Damann KE, Benda GIA (1983) Evaluation of commercial heattreatment methods for control of ratoon stunting disease of sugarcane. Plant Disease 67, 966-967.

Davis MJ, Dean JL (1984) Comparison of diagnostic techniques for determining incidence of ratoon stunting disease of sugarcane in Florida. Plant Disease 68, 896-899.

Davis MJ, Gillaspie AG Jr, Harris RW, Lonson RH (1980) Ratoon stunting disease of sugarcane: Isolation of the causal bacterium. Science 210, 1365-1367.

Davis MJ, Gillaspie AG Jr, Vidaver AK, Harris RW (1984) Clavibacter: a new genus containing some phytopathogenic coryneform bacteria, including Clavibacter xyli subsp. xyli sp. nov., subsp. nov. and Clavibacter xyli subsp. cynodontis subsp. nov. pathogens that cause ratoon stunting disease of sugarcane and bermudagrass stunting disease. International Journal of Systematic Bacteriology 34, 107-117.

Dong Y-H, Xu J-L, Li X-Z, Zhang L-H (2000) AiiA, an enzyme that inactivated the acylhomoserine lactone quorum-sensing signal and attenuates the virulence of Erwinia carotovora. Proceedings of the National Academy of Science, USA 97, 3526-3531.

Dong Y-H, Wang L-H, Xu J-L, Zhang H-B, Zhang X-F, Zhang L-H (2001) Quenching quorum-sensing-dependent bacterial infection by an N-acyl homoserine lactonase. Nature 411, 813-816. doi: $10.1038 / 35081101$

Dreier J, Meletzus D, Eichenlaub R (1997) Characterization of the plasmid encoded virulence region pat-1 of phytopathogenic Clavibacter michiganensis subsp. michiganensis. Molecular PlantMicrobe Interactions 10, 195-206.

Evtushenko L, Dorofeeva L, Subbotin J, Tiedje J (2000) Leifsonia poae, gen. nov., sp. nov., isolated from nematode galls on Poa annua, and reclassification of 'Corynebacterium aquaticum' Leifson 1962 as Leifsonia aquatica (ex Leifson 1962) gen. nov., nom. rev., comb. nov. and Clavibacter xyli Davis et al. 1984 with two subspecies as Leifsonia xyli (Davis et al. 1984) gen. nov., comb. nov. International Journal of Systematic and Evolutional Microbiology 50, 371-380.

Fegan M, Croft BJ, Teakle DS, Hayward AC, Smith GR (1998) Sensitive and specific detection of Clavibacter xyli subsp. xyli, causative agent of ratoon stunting disease of sugarcane, with a polymerase chain reaction-based assay. Plant Pathology 47, 495504. doi: 10.1046/j.1365-3059.1998.00255.x

Gillaspie AG, Teakle DS (1989) Ratoon stunting disease. In 'Diseases of Sugarcane'. (Eds C Ricaud, BT Egan, AG Gillaspie, CG Hughes) pp. 59-80. (Elsevier Publishing Company: Amsterdam)

Gillaspie AG, Davis RE, Worley JF (1973) Diagnosis of ratoon stunting disease based on the presence of a specific microorganism. Plant Disease Reporter 57, 987-990.
He SY, Collmer A (1990) Molecular cloning, nucleotide sequence, and marker exchange mutagenesis of the exo-poly-alpha-Dgalacturonosidase-encoding pehX gene of Erwinia chrysanthemi EC16. Journal of Bacteriology 172, 4988-4995.

Hinton JCD, Hautefort I, Eriksson S, Thompson A, Mikael R (2004) Benefits and pitfall of using microarrays to monitor bacterial gene expression during infection. Current Opinion in Microbiology 7 , 277-282. doi: 10.1016/j.mib.2004.04.009

Hughes CG (1955) Ratoon stunting disease of sugar cane. Journal of the Australian Institute of Agricultural Science 10, 3-9.

Kao J, Damann KE Jr (1978) Microcolonies of the bacterium associated with ratoon stunting disease found in sugarcane xylem matrix. Phytopathology 68, 545-551.

Kao J, Damann KE Jr (1980) In situ localisation and morphology of the bacterium associated with ratoon stunting disease of sugarcane. Canadian Journal of Botany 58, 310-315.

Keen NT, Tamaki S, Kobayashi D, Trollinger D (1988) Improved broadhost-range plasmids for DNA cloning in Gram-negative bacteria Gene 70, 191-197. doi: 10.1016/0378-1119(88)90117-5

King NJ (1953) The ratoon stunting disease problem. Cane Growers' Quarterly Bulletin 17, 10-13.

King NJ, Steindl DRL (1953) The relationship between varietal yield deterioration and ratoon stunting disease. Cane Growers' Quarterly Bulletin 17, 64-73.

Koike H, Gillaspie AG, Benda GTA (1982) Cane yield response to ratoon stunting disease. International Sugar Journal 84, 131-133.

Lu S-E, Wang N, Wang J, Chen ZJ, Gross DC (2005) Oligonucleotide microarray analysis of the SalA regulon controlling phytotoxin production by Pseudomonas syringae pv. syringae. Molecular Plant-Microbe Interactions 18, 324-333.

McDougall WA, Steindl DRL, Elliott JT (1948) Variations in primary vigour in the variety Q.28. Cane Growers' Quarterly Bulletin 12, $31-34$.

Matsuoka S (1971) Elephant grass, an indicator for ratoon stunting virus of sugarcane. FAO Plant Protection Bulletin 19, 110-115.

Magarey RC, Suma S, Irawan, Kuniata LS, Allsopp PG (2002) Sik na binatang bilong suka - diseases and pests encountered during a survey of Saccharum germplasm 'in the wild' in Papua New Guinea. Proceedings of the Australian Society of Sugar Cane Technologists 24, 219-227.

Meletzus D, Bermpohl A, Dreier J, Eichenlaub R (1993) Evidence for plasmid-encoded virulence factors in the phytopathogenic bacterium Clavibacter michiganensis subsp. michiganensis NCPPB382. Journal of Bacteriology 175, 2131-2136.

Mills L, Leaman TM, Taghavi SM, Shackel L, Dominiak BC, Taylor PWJ, Fegan M, Teakle DS (2001) Leifsonia-like bacteria are endophytes of grasses in eastern Australia. Australasian Plant Pathology 30, 145-151. doi: 10.1071/AP01003

Monteiro-Vitorello CB, Camargo LEA, Van Sluys MA, Kitajima JP, Truffi D et al. (2004) The genome sequence of the Gram-positive sugarcane pathogen Leifsonia xyli subsp. xyli. Molecular PlantMicrobe Interactions 17, 827-836.

Mudge SR, Lewis-Henderson WR, Birch RG (1996) Comparison of Vibrio and firefly luciferases as reporter gene systems for use in bacteria and plants. Australian Journal of Plant Physiology 23, $75-83$.

Okinaka Y, Yang C-H, Perna NT, Keen NT (2002) Microarray profiling of Erwinia chrysanthemi 3937 genes that are regulated during plant infection. Molecular Plant-Microbe Interactions $\mathbf{1 5}$ 619-629.

Padliya ND, Cooper B (2006) Mass spectrometry-based proteomics for the detection of plant pathogens. Proteomics 6, 4069-4075. doi: $10.1002 /$ pmic. 200600146 
Pan YB, Grisham MP, Burner DM, Damann KE, Wei Q (1998) A polymerase chain reaction protocol for the detection of Clavibacter $x y l i$ subsp. $x y l i$, the causal bacterium of ratoon stunting disease. Plant Disease 82, 285-290.

Plavsic-Banjac B, Maramorosch K (1972) Electron microscopy of the xylem of ratoon stunted sugarcane. Phytopathology 62, 498-499.

Rao GP, Singh M, Singh HN (1990) Alternative hosts of sugarcane diseases. Sugar Cane Autumn (Supplement), 8-26.

Roach BT (1987) Observations on the incidence, effects and control of ratoon stunting disease. Proceedings of the International Society of Sugar Cane Technologists 9, 109-116.

Roach BT (1988) Assessment of varietal susceptibility to ratoon stunting disease of sugarcane. Proceedings of the Australian Society of Sugar Cane Technologists 10, 171-177.

Roach BT (1990) Sampling and diagnostic procedures for testing sugarcane resistance to ratoon stunting disease by phase contrast microscopy. Proceedings of the Australian Society of Sugar Cane Technologists 12, 111-119.

Roach BT, Jackson PA (1992) Screening sugarcane clones for resistance to ratoon stunting disease. Sugar Cane 2, 2-12.

Rott P, Davis MJ, Baudin P (1994) Serological variability in Xanthomonas albilineans, causal agent of leaf scald disease of sugarcane. Plant Pathology 43, 344-349.

Shaw JJ, Settles LG, Kado CI (1988) Transposon Tn4431 mutagenesis of Xanthomonas campestris pv. campestris: Characterization of a non-pathogenic mutant and cloning of a locus for pathogenicity. Molecular Plant-Microbe Interactions 1, 39-45.

Staskawicz B, Dahlbeck D, Keen N, Napoli C (1987) Molecular characterization of cloned avirulence genes from race 0 and race 1 of Pseudomonas syringae pv. syringae. Journal of Bacteriology 169, 5789-5794.

Steib RJ, Chilton SJP (1968) The role of ratoon stunting disease in the determination of sugarcane varieties. The Sugar Journal May, 10-12.
Steindl DRL (1957) Host range of the ratoon stunting disease virus. Journal of the Australian Institute of Agricultural Science 23, 238.

Steindl DRL (1961) Ratoon stunting disease. In 'Diseases of the world. Vol. I'. (Eds JP Martin, EV Abbot, CG Hughes) pp. 432-459. (Elsevier Publishing Company: Amsterdam)

Taylor PWJ, Ryan CC, Birch RG (1988) Harvester transmission of leaf scald and ratoon stunting disease. Sugar Cane 4, 11-14.

Taylor PWJ, Petrasovits LA, Van der Velde R, Birch RG, Croft BJ, Fegan M, Smith GR, Brumbley SM (2003) Development of PCR-based markers for detection of Leifsonia xyli subsp. xyli in fibrovascular fluid of infected sugarcane plants. Australasian Plant Pathology 32, 367-375. doi: 10.1071/AP03036

Teakle DS, Ryan CC (1992) The effect of high temperature on the sugar cane ratoon stunting bacterium, Clavibacter xyli subsp. xyli, in vitro and in vivo. Sugar Cane 6, 5-6.

Toth IK, Pritchard L, Birch PRJ (2006) Comparative genomics reveals what makes an Enterobacterial plant pathogen. Annual Review of Phytopathology 44, 305-336. doi: 10.1146/ annurev.phyto.44.070505.143444

Young AJ, Brumbley SM (2004) Ratoon stunting disease: history, management and current research. In 'Sugarcane pathology. Volume III: Bacterial and nematode diseases'. (Eds GP Rao, AS Saumtally, P Rott) pp. 97-124. (Science Publishers, Inc.: Enfield, NH)

Young AJ, Petrasovits LA, Croft BJ, Gillings M, Brumbley SM (2006) Genetic uniformity of international isolates of Leifsonia $x y l i$ subsp. $x y l i$, causal agent of ratoon stunting disease of sugarcane (Saccharum interspecific hybrids). Australasian Plant Pathology 35, 503-511. doi: 10.1071/AP06055

Zhang L-H (2003) Quorum quenching and proactive host defense. Trends in Plant Science 8, 238-244. doi: 10.1016/S13601385(03)00063-3

Received 10 April 2006, accepted 21 September 2006 